\title{
Evaluation of the Effect of Temperature on the Ore Leaching Process
}

\author{
AT Kanayev*, KM Baimurzaev and ZK Kanaeva \\ Al-Farabi Kazakh National University, Kazakhstan \\ *Corresponding author: AT Kanayev, Institute of Microbiology and Virology, CNMONRK, Kazakhstan
}

Submission: October 25, 2018; Published: January 25, 2019

\begin{abstract}
The optimum temperature for the process of the bacterial-chemical method of leaching gold from the Bolshevik ore deposit was chosen in the paper given. As a result of the study, it was established that the maximum extraction of gold in the solution does not depend on increasing the temperature of the leachable medium $\left(40{ }^{\circ} \mathrm{C}\right)$. Temperature range from 20 to $30^{\circ} \mathrm{C}$, which is considered optimal for the growth and development of acidophilic cultures of bacteria, is sufficient.
\end{abstract}

Keywords: Leaching; Mode; Temperature; Gold; Bacteria; Deposits

\section{Relevance}

The widespread introduction of effective bioleaching technology by the leading gold mining countries including the USA, Australia, South Africa, Canada not only allowed to increase gold production by 2-3 times over the last thirty years, but also significantly reduced the cost of ore processing [1]. Heap bioleaching is complicated at deposits in Kazakhstan because of severe climatic conditions. In this regard, it is believed that to increase the extraction of gold at the lowest cost an optimization of the temperature regime of leaching technology is needed. This can be done if there is a kinetic model that takes into account the effect of temperature on the rate of gold extraction from ore.

\section{Objects, Materials and Methods of Research}

The experiment was carried out involving the ore of the Bolshevik Deposit, which is classified as gold-arsenic in content. The Bolshevik field is located $34 \mathrm{~km}$ east of the Charsk railway station in the Zharma district of East Kazakhstan region [2]. The Bolshevik deposit is the westernmost point of the Bakyrchik gold ore field and is located only $6 \mathrm{~km}$ west of the main field deposit Bakyrchik. Many features of the latter were also characteristic of the Bolshevik deposit. It is confined to the zone of regional overthrust, representing the structural element of the so-called Kyzylovski zone of crumple. The hanging (northern) side of the overthrust is dominated by polymictic and volcaniclastic sandstones with facially wedged extended lenses and layers of conglomerates. These rocks are crumpled into relatively small isoclinal folds [3] Figure 1.

The amount of $\mathrm{Fe}^{2+}$ and $\mathrm{Fe}^{3+}$ was determined by complexometry according to the method proposed by A. A. Reznikov [4], using EDTA (ethylenediaminetetraacetic acid disodium salt) as a titrant or Trilon B as a titrant. Three strains of chemolithotrophic bacteria in the following association served as objects of the research:

a. Acidithiobacillus ferrooxidans: A culture extracted on one's own from the sulfuric acid solution after the heap leaching stage of the off-balance ore of the "Vostok" uranium deposit of the Stepnogorsk mining and chemical combine.

b. Acidithiobacillus acidocaldulans: A culture which is kindly provided by the head of the "Biotechnology" FRC laboratory of chemolithotrophic microorganisms of the Russian Academy of Sciences.

c. Acidiplasma sp: A culture which is kindly provided by the head of the "Biotechnology" FRC laboratory of chemolithotrophic microorganisms of the Russian Academy of Sciences.

The medium of Silverman and Lundgren, the so-called 9K, was used as a nutrient medium. The medium was composed of 2 solutions. They were prepared separately and had the following composition (g/l): the $1^{\text {st }}$ solution: $\left(\mathrm{NH}_{4}\right)_{2} \mathrm{SO}_{4}-3,0 ; \mathrm{K}_{2} \mathrm{HPO}_{4}-0,5$; $\mathrm{MgSO}_{4} \cdot \mathrm{H}_{2} \mathrm{O}-0,5 ; \mathrm{KCl}-0,1 ; \mathrm{Ca}\left(\mathrm{NO}_{3}\right)_{2}-0,01$ were dissolved in $700 \mathrm{ml}$ of distilled water.

$2^{\text {nd }}$ solution: $\mathrm{FeSO}_{4} \cdot 7 \mathrm{H}_{2} \mathrm{O}-44,22$ was dissolved in $300 \mathrm{ml}$ of distilled water, $1 \mathrm{ml}$ of $10 \mathrm{H} \mathrm{H}_{2} \mathrm{SO}_{4}$ was added. The prepared solutions were mixed, the $\mathrm{pH}$ of the medium was brought to 2.0 .

\section{Research Results}

We began our research with the study of agitation leaching in the laboratory, as shown in Scheme 1. The experiment started with ore preparation. For this purpose, the selected ore was subjected 
to grinding to a grain size of $0.074 \mathrm{~mm}$ in a ball mill Figure 2 . In the first stage the ore was exposed to bioleaching, while in the second stage the actual extraction of gold was carried out. The temperature regime was provided by cultivation and leaching of both the first and the second stages in a thermostated shaker Figure 3. Temperature regimes of $20{ }^{\circ} \mathrm{C}, 30{ }^{\circ} \mathrm{C}$ and $40{ }^{\circ} \mathrm{C}$ were investigated. The ratio of solid to liquid - $\mathrm{S}$ : $\mathrm{L}=1: 1.5$.

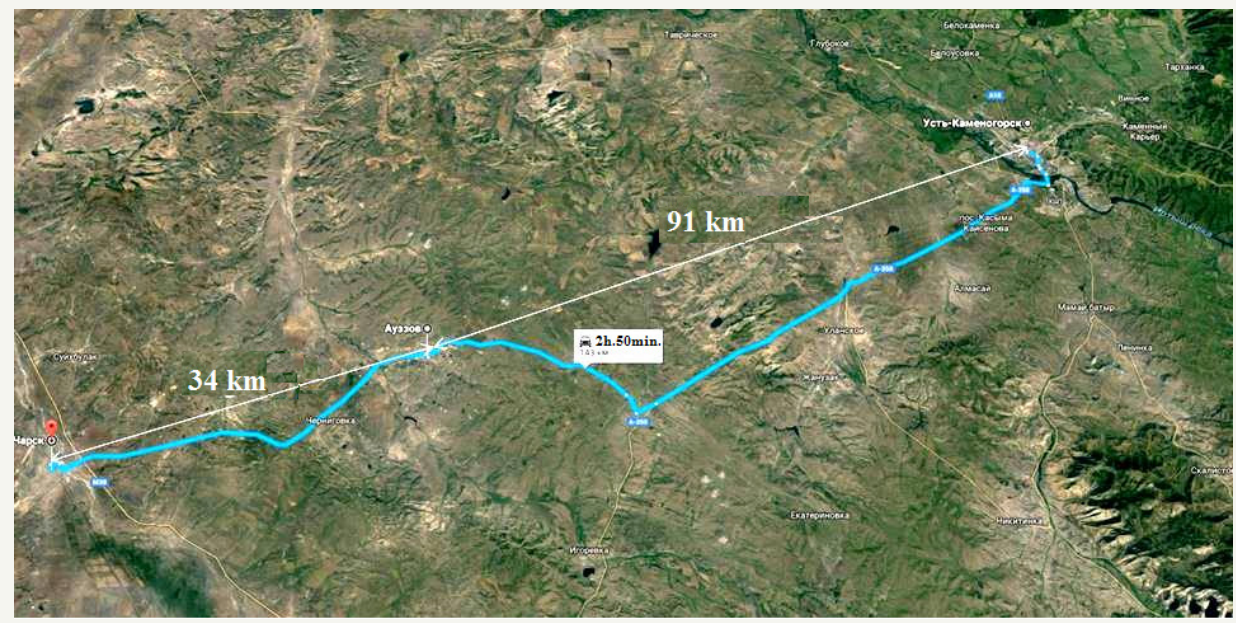

Figure 1: Geographical location of the gold-arsenic bolshevik deposit.

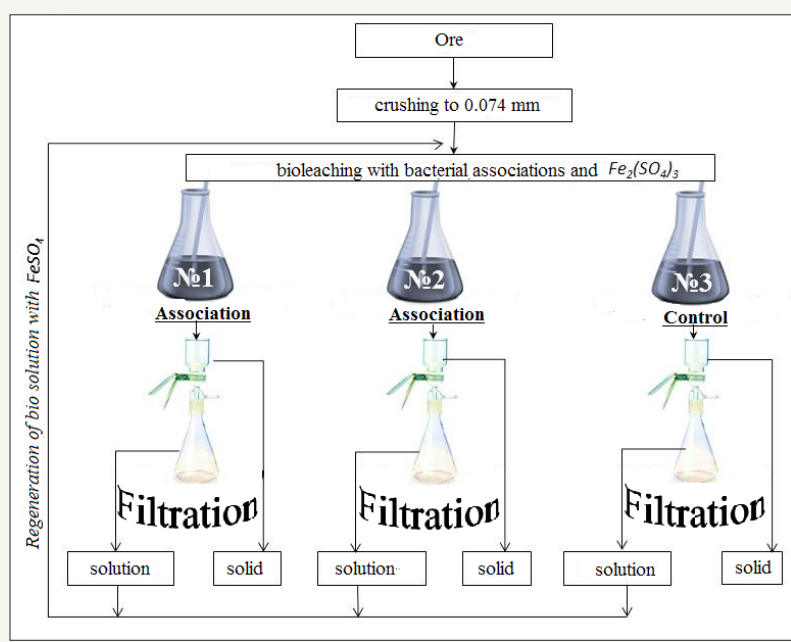

Scheme 1: Stages of the bacterial-chemical method of leaching of the gold-bearing ore in the bolshevik deposit.

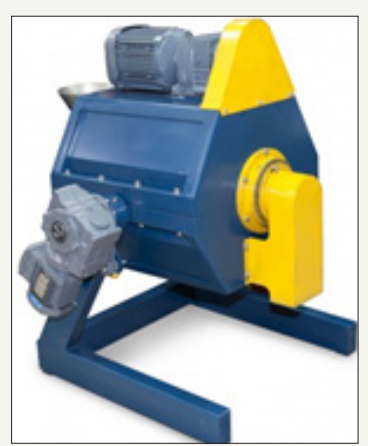

Figure 2: Laboratory grinding device of ore.

The ore of the Bolshevik gold-arsenic deposit belongs to the geological-industrial type of gold ore objects, localized in the rocks of carbonaceous sandstone-shale formations. This is an important industrial type of gold deposits. One of the factors that intensify the process of cyanidation of gold-containing ores of any type can be the temperature of the leaching solution [5].

To carry out the experiment, the ore of the Bolshevik deposit of the following composition was used, g/t: $\mathrm{Au}-2,9 ; \%$ : Fe-3,4; $\mathrm{Cu}-0,02$; S-1,2; As- 0,91. The objects of the research study, as indicated in the "Methods of Research" section, were cultures of Acidithiobacillus ferrooxidans, Asidithiobacillus acidocaldulans, and Acidiplasma sp. The duration of the process was 24, 48 and 72 hours. The obtained data are given in Table 1.

Table 1 shows a significant intensification of the thiosulfate leaching process with an increase in the process temperature. However, the effect of temperature on core samples pretreated by bacterial culture looks ambiguous. In the first case, it is so strong that negative phenomena appear, which are manifested in an 
increase in the kinetic complications leading to the destruction of thiosulfate complexes and metal reprecipitation, as indicated by a sharp decrease in gold recovery at $40{ }^{\circ} \mathrm{C}$.

The productive process mainly takes place during the first 24 hours. In this case, it is necessary to reduce the duration of thiosulfate leaching to 8-12 hours. The process with bacterial pretreatment by the association of cultures №2 is more resistant to temperature changes. In the control variants, the process goes in a classical way, i.e., the temperature increase leads to an increase in the gold recovery rate Figure 4.

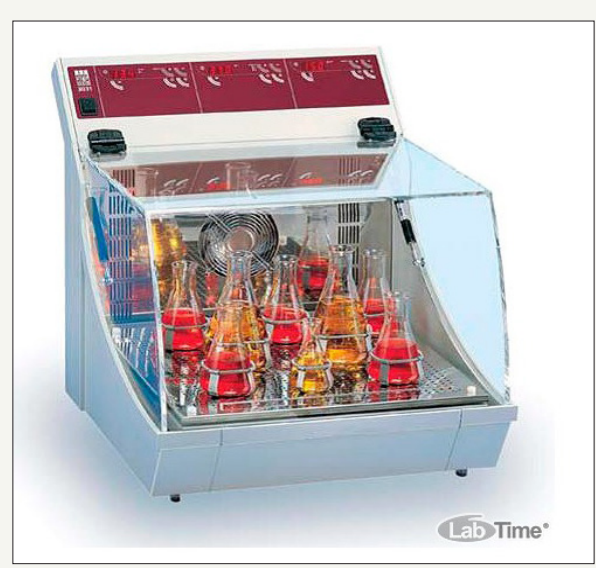

Figure 3: Shaker-incubator GFL.

3031 for maintaining the temperature.

Table 1: Effects of temperature on gold extraction from the ore of the bolshevik deposit.

\begin{tabular}{|c|c|c|c|c|c|c|}
\hline \multirow{2}{*}{$\begin{array}{c}\text { Duration of } \\
\text { Leaching, } \\
\text { Hour }\end{array}$} & \multirow{2}{*}{$\begin{array}{c}\text { The Initial Au Con- } \\
\text { centration in the } \\
\text { Ore, } \%\end{array}$} & \multirow{2}{*}{$\begin{array}{c}\text { Ore Size } \\
\text { Class, } \\
\text { mm }\end{array}$} & \multirow[b]{2}{*}{ Temperature ${ }^{\circ} \mathrm{C}$} & \multicolumn{3}{|c|}{ Gold Recovery,\% } \\
\hline & & & & $\begin{array}{c}\text { With Culture } \\
\text { Association №1 }\end{array}$ & $\begin{array}{l}\text { With Culture Association } \\
\text { №2 }\end{array}$ & $\begin{array}{l}\text { Control Without Associ- } \\
\text { ation of Cultures }\end{array}$ \\
\hline \multirow{3}{*}{24} & \multirow{3}{*}{2,9} & \multirow{3}{*}{0,074} & 20 & 85,2 & 94,5 & 12,9 \\
\hline & & & 30 & 78,0 & 92,4 & 27,8 \\
\hline & & & 40 & 25,0 & 14,2 & 54,7 \\
\hline \multirow{3}{*}{48} & \multirow{3}{*}{2,9} & \multirow{3}{*}{0,074} & 20 & 86,0 & 94,6 & 13,3 \\
\hline & & & 30 & 78,0 & 94,6 & 27,9 \\
\hline & & & 40 & 31,2 & 22,5 & 63,2 \\
\hline \multirow{3}{*}{72} & \multirow{3}{*}{2,9} & \multirow{3}{*}{0,74} & 20 & 88,4 & 94,9 & 15,6 \\
\hline & & & 30 & 78,1 & 94,8 & 31,4 \\
\hline & & & 40 & 39,1 & 27,6 & 66,6 \\
\hline
\end{tabular}

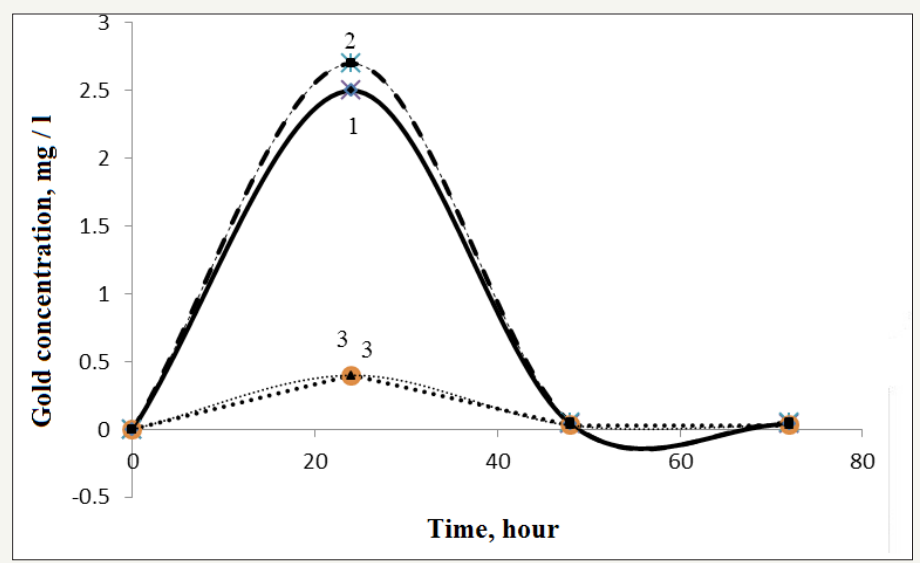

Figure 4: Dynamics of gold extraction from the bolshevik ore deposit at $20{ }^{\circ} \mathrm{C}$.

Note: 1-association 1, 2 - association 2, 3 - control 
Analyzing the data on the concentration of dissolved gold shown in Figure 1-3, it should be noted that the best temperature regime for biochemical leaching is maintaining the temperature at
$30{ }^{\circ} \mathrm{C}$, the concentration of gold in 24 hours rises to $3,1 \mathrm{mg} / \mathrm{l}$. In the control variant, it does not reach $1.0 \mathrm{mg}$ l Figure 5.

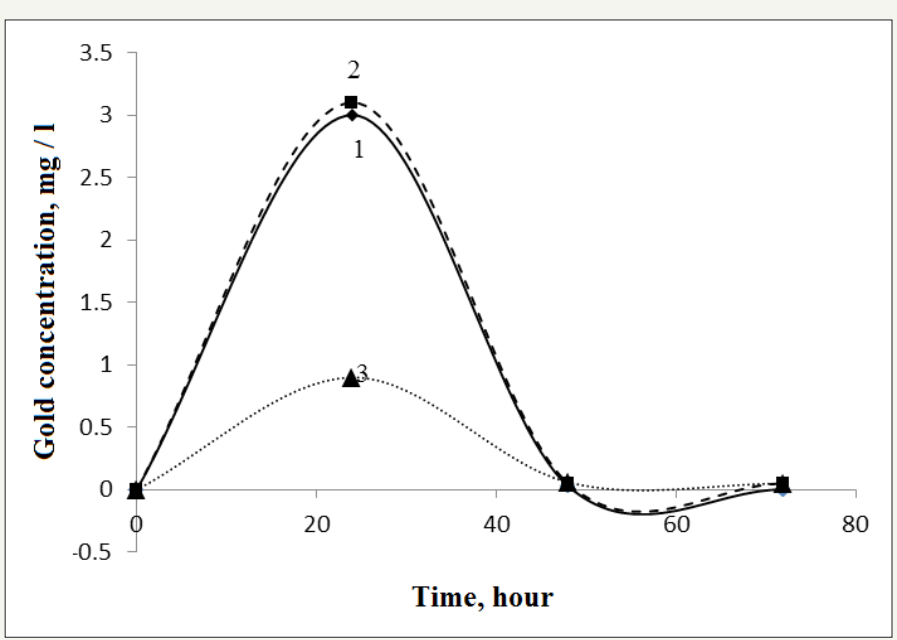

Figure 5: Dynamics of gold extraction from the bolshevik ore deposit at $30{ }^{\circ} \mathrm{C}$.

Note: 1- association 1, 2 - association 2, 3 - control

However, increasing the temperature to $40{ }^{\circ} \mathrm{C}$ dramatically changes the whole picture: the concentration of gold by the end of 24 hours drops sharply with bioleaching, while in the control it increases significantly. Considering the processes in terms of profitability, the energy costs for maintaining the temperature of $40{ }^{\circ} \mathrm{C}$ are higher than $30{ }^{\circ} \mathrm{C}$, so the biochemical process is more economical Figure 6.

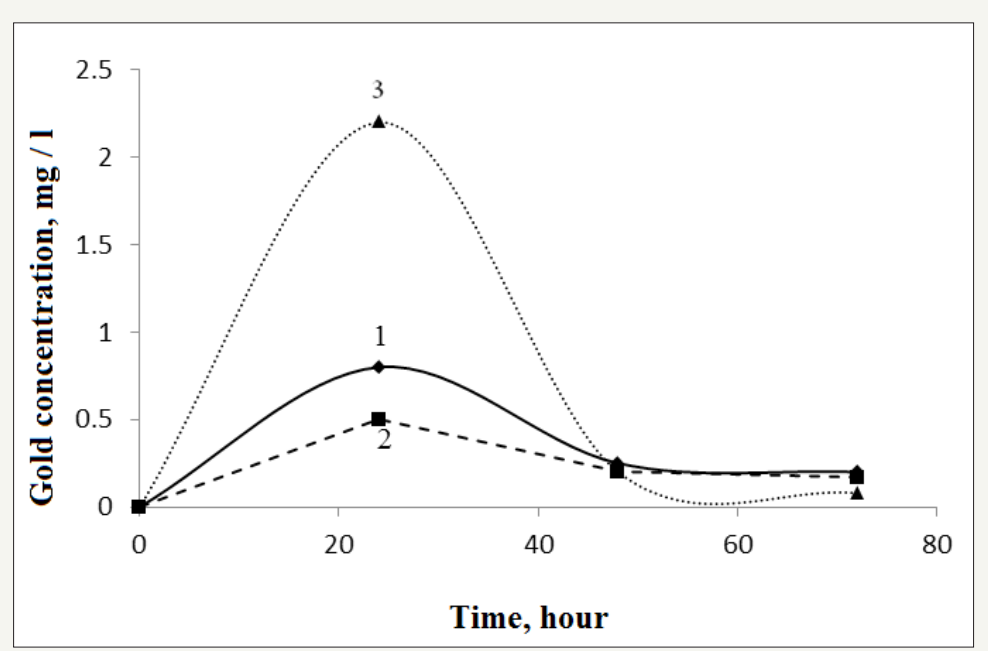

Figure 6: Dynamics of gold extraction from the bolshevik deposit at $40{ }^{\circ} \mathrm{C}$.

Note: 1- association 1, 2 - association 2, 3-control.

\section{Conclusion}

So the effect of temperature significantly intensifies both biochemical and chemical processes of gold extraction from the ore of the Bolshevik Deposit. The optimum for biochemical thiosulfate leaching should be considered $20-30{ }^{\circ} \mathrm{C}$. Herewith the duration of the process can be reduced to 8-12 hours.

\section{References}

1. Shesternev DM, Myazin VP, Bayanov AE (2015) Heap leaching of gold in the cryolitization of Russia. pp. 51-53
2. Tarkhov SA (2004) Change of administrative-territorial division of Russia in the XIII-XX centuries. Moscow, Russia.

3. Kanaev AT, Baymyrzaev KM (2017) Enlarged laboratory bacterialchemical leaching of gold from ore from the Bolshevik deposit.

4. Reznikov AA, Mulikovskaya EP, Sokolov IY (1970) Methods of analysis of natural waters.

5. Kholmatov MM, Kalinin VP (2003) Problems of processing of technogenic waste. pp. 10-11. 
Creative Commons Attribution 4.0 International License

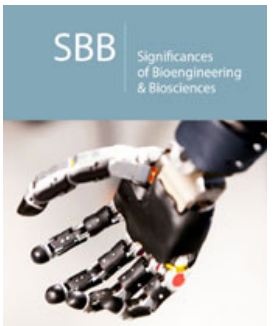

\section{Significances of Bioengineering \& Biosciences}

\section{Benefits of Publishing with us}

- High-level peer review and editorial services

- Freely accessible online immediately upon publication

- Authors retain the copyright to their work

- Licensing it under a Creative Commons license

- Visibility through different online platforms 